\title{
IAMJ
}

INTERNATIONAL

AYURVEDIC

MEDICAL JOURNAL

\section{A CROSS-SECTIONAL STUDY TO ASSESS THE IMPACT OF DIET \& LIFESTYLE IN PREVALENCE OF HYPOTHYROIDISM IN FEMALES - AN AYURVEDIC PERSPECTIVE}

\author{
Pavan Kumar K ${ }^{1}$, Sudhakar P Reddy ${ }^{2}$ \\ ${ }^{1}$ M.D. Scholar, ${ }^{2}$ Professor and Head, \\ Post Graduate Department of Swasthavritta, J.S.S. Ayurveda Medical College, Mysuru, Karnataka, India
}

Corresponding Author: dr.pavankumar1988@gmail.com

\section{https://doi.org/10.46607/iamj0809122021}

(Published Online: December 2021)

Open Access

(C) International Ayurvedic Medical Journal, India

Article Received: 27/11//2021 - Peer Reviewed: 10/12/2021 - Accepted for Publication 11/12/2021

\section{Check for updates}

\begin{abstract}
Background: In India, 42 million people are suffering from thyroid disorders, out of which hypothyroidism is most common with a prevalence of 5.4\%. It is more prevalent among females with the male-female ratio being 1:6. Hypothyroidism is a clinical syndrome resulting from a deficiency of thyroid hormones, which in turn results in a generalized slowing down of metabolic processes. Impaired metabolism can be compared with vitiation of Agni causing Agnimandhya according to Ayurveda. Agnimandhya further hampers the formations of Ahara Rasa and consecutive Dhatus Nirmana, diminishing the metabolism, thereby causing features similar to hypothyroidism. The objective of the Study: To assess the impact of diet \& lifestyle on the prevalence of Hypothyroidism in Females. Materials and Methods: It is a cross-sectional survey study. A total of 150 female subjects were selected for the study. With the help of a validated pre-designed and pre-tested questionnaire, the interview was conducted on female subjects diagnosed with Hypothyroidism to assess the impact of diet and lifestyle on the prevalence of Hypothyroidism in and around Mysuru city. Result: In the survey study, the majority of the hypothyroidism diagnosed subjects followed unhealthy daily regimes and the majority percentage of them practised unwholesome diet, food habits and lifestyle. Diet and lifestyle have a direct influence on the occurrence of hypothyroidism. Conclusion: Hypothyroidism is a metabolic disorder is mainly caused by Agni Mandhya and Rasa Pradoshaja as a result of
\end{abstract}


faulty diet and lifestyle. One should follow Dincharya, Rutucharya and other Ayurveda principles to protect the Agni and thereby prevent Hypothyroidism. The practice of Ahita Ahara Vidhi and Ahita Vihara in the manifestation of Agnimandhya, followed by the development of features of hypothyroidism was substantiated by the result of the survey.

Keywords: Hypothyroidism; Diet; Lifestyle; Agnimandhya; Rasa Pradoshaja Vikara.

\section{INTRODUCTION}

The normalcy of all mechanisms of the body is dependent upon the normal functioning of Agni. According to allopathic systems, the metabolic activity of the body is controlled by thyroid hormone secretion and if we move our eyes towards Ayurveda, we will find that metabolic processes of the body are under the control of Jatharagni, Bhutagniand Dhatvagni, as quoted by Charaka. Most of the features of hypothyroidism are similar to the Lakshanas of Agnimandhya ${ }^{[1]}$ and Rasapradoshaja Vikaras. ${ }^{[2]}$ The causative factors of $\mathrm{Ag}$ nimandhya and Rasapradoshaja Vikaras are the frequent practice of unhealthy diet and lifestyle in daily life, excess use of readymade/packed/refrigerated food, consumption of food in urgency, overeating etc. along with the practice of sedentary lifestyle with minimal exercises, faulty sleeping habits etc. Women go through a lot of hormonal variations during puberty, pregnancy, menstruation, menopause etc. which may interfere with the normal functioning of the thyroid hormone. Therefore, an attempt has been made here to study the diet and lifestyle practice of women suffering from Hypothyroidism, considering the lifestyle and diet prescribed in Ayurveda, a practical questionnaire is prepared and surveyed. Factors concerning Agnimandhya, Rasa Pradoshaja Vikara as described in Ayurveda classics along with Ahara Vidhi, Dinacharya Ritucharya Paripalana in routine life is asked among the subjects and are surveyed.

\section{MATERIALS AND METHODS}

A total of 150 female subjects diagnosed with Hypothyroidism, in the age group of 18-60 years, visited the O.P.D. and I.P.D. of J.S.S. Ayurveda Medical College \& Hospital, Mysuru, were taken for the survey study. Inclusion Criteria:

1. Female subjects with Hypothyroidism in the age group of 18-60 years
2. Serum TSH, T3 and T4 levels which indicate Hypothyroidism

3. Subjects of Hypothyroidism on regular medications

4. Subjects consenting to participate in the study

Exclusion criteria:

1. Subjects associated with congenital Hypothyroidism

2. Pregnant women \& lactating mother

Survey method: With a validated pre-designed and pre-tested questionnaire, the interview was conducted to assess the impact of diet and lifestyle on the prevalence of Hypothyroidism in and around Mysuru city. Assessment of the role of diet \& lifestyle in the prevalence of Hypothyroidism was done by questionnaire.

\section{Statistical Data Analysis:}

The information gathered based on the survey was analyzed with descriptive statistics.

\section{RESULT}

A total of 150 female subjects were surveyed. Among them, Adhyashana was practised by $41.33 \%$ of subjects, $38 \%$ of the subjects had poor appetite, $41.33 \%$ subjects had irregular bowel habits, $40 \%$ subjects had constipation, $27.33 \%$ had disturbed sleep, and $14.66 \%$ had excess sleep. $51.33 \%$ of subjects wake up between 7 am-9 am, Abhyanga was practised only by $34.66 \%$ of subjects and Vyayama only by 20\%, 63.66\% of subjects sleep between $10 \mathrm{pm}-12$ am and $50.66 \%$ sleep for $8-10 \mathrm{hrs}$ at night. $66 \%$ of people had the habit of sleeping during the day and among them, $43.43 \%$ people sleep for 1-2 hr. $45.33 \%$ practised Ratrijagarana out of which $80.88 \%$ had the habit to remain awake upto12am-2am.

$77.33 \%$ consumed freshly prepared food when it is hot, $66 \%$ of the subjects consumed unctuous food, $52.66 \%$ of the subjects consumed proper quantity of 
food, $42 \%$ of the survey population consumed food only after digestion of previous meal/when they feel hungry, $65.33 \%$ subjects consume food with contradictory potency, $38 \%$ people consumed food in a hurry/ very slow. $64.66 \%$ population had the habit of talking/laughing/watching TV while having food. $78.66 \%$ had the habit of sleeping soon after having food in the afternoon, $46 \%$ of the survey population used to sleep within 5min-30min after dinner, $41.33 \%$ used to take food soon after bathing, $43.33 \%$ population had a habit of having a bath just after having food. $40 \%$ of the survey population consumed breakfast after $11 \mathrm{am}, 52 \%$ of the survey population consumed lunch between $12 \mathrm{pm}-2 \mathrm{pm}, 73.33 \%$ of the survey population consumed dinner between 8pm-10pm, 42\% consumed tea/coffee 1-2 times a day $60.66 \%$ skip meals, $67.16 \%$ consumed meat/egg 1-2 days a week, $36 \%$ people feel hungry soon after meal, $55.33 \%$ population does not consume food in excess, $89.33 \%$ subjects took heavy/fatty foods, $60 \%$ experienced indigestion, $56 \%$ experienced anorexia/loss of appetite, $50 \%$ experienced bloating of abdomen, $68 \%$ experienced burning in abdomen/ chest, $56 \%$ subjects experienced eructation with the taste/smell of previous meal, $62 \%$ of the subjects complained of excessive salivation, $40 \%$ subjects experienced dryness of mouth, 58.66\% consume less salt in their diet, $59.33 \%$ were consuming iodine rich food, $62 \%$ of the subjects consumed more of gluten in diet, $74.66 \%$ of the subjects consumed dairy and sweets, $81.33 \%$ of the subjects consumed curds at night, $79.33 \%$ of the subjects consumed caffeine drinks/carbonated drinks, $88 \%$ people consumed cruciferous vegetables, $72.66 \%$ people consumed unhealthy dietary products and $63.33 \%$ subjects had the habit of consuming excess food when mood is not good (stress/fear/worry/stress eating).

\section{DISCUSSION}

Lack of exercise, physical activity, waking up very late in the morning cause Kapha vitiation, which hampers metabolic functions. Disturbance in sleep habits, oversleep and untimely sleep cause imbalance in the biological clock of the body hampering the hormonal balance, which further cause Agni Dushti, Vata Prakopa and Kapha Dushti. Weight gain, irritability, lethargy, constipation, puffiness, anorexia, indigestion may also anticipate. Excess quantity of food intake may cause Agnimandhya, Ama formation and less quantity may cause Dhatu Kshaya, Agni Vaishamya and other disorders; taking food before the digestion of previous food, when not hungry also causes Agnimandhya, Adhmana, Aruchi, sluggishness of metabolism process. Consuming contradictory potency food can cause Ama, further deteriorate the hypothyroidism features; Eating food in a hurry/very slow or eating along with talking/laughing/distracted mind, doesn't serve the purpose of providing nutrition, instead delays the digestion process. It can be observed that maximum subjects did not follow the dietary rules/Ahara Vidhi which may be the leading cause for the manifestation of Agnimandhya, Rasa Dushti thereby leading to hypothyroidism. Sleeping in the noon itself aggravates Kapha causing lethargy, heaviness of body and weight gain. Sleeping soon after taking food causes Agnimandhya. Lack of physical activity after food intake causes the digestion process to slow down, the digestion process is hampered causing indigestion and other GIT disturbances. Taking bath improves the Agni and digestion however taking bath soon after having food causes Agnimandhya and digestion complications. Disturbance in Lifestyle as irregular schedules of sleep and diet, improper dietary habits mainly affect the Ahara Parinamakara Bhavas and circadian rhythm which leads to the manifestation of many diseases. First of them is Agnimandya which is a root cause for many diseases. Taking food untimely and skipping the meals hampers the Agni and metabolism. Indigestion, anorexia, nausea, loss of appetite, bloating of the abdomen, heartburn, eructation, excess salivation, dryness of the mouth; all these features are seen in hypothyroidism and are the chief features of Agnimandhya, Ama and Rasa Pradosha. Gluten rich diet such as barley, wheat products, bread, chapatti, roti contains high levels of lectins, saponins, and protease inhibitors which affects thyroid functioning. ${ }^{[3]}$ Milk/dairy products/excess sweets, milk, yoghurt, butter, ice cream, curds contain A1 casein which can cause leaky gut syndrome and increase inflammation in the thyroid 
gland and ultimately affect its function. ${ }^{[4]}$ Caffeine and carbonated drinks hamper the normal digestion process, contains excess sugar and worsen metabolic disorders. ${ }^{[5]}$ Natural sweeteners such as agave are pure fructose, which can tease the body into thinking because it is sweet, that it needs to release insulin to digest the glucose before realizing there is no glucose to digest. Cruciferous vegetables such as cabbage, cauliflower and soya are rich in glucosinolates compounds which further inhibit thyroid hormone. ${ }^{[6]}$ Consuming packed/ bakery/ readymade/ processed/canned/preservative foods/ refrigerated/ stale/ previous day food/ leftovers/fast food as it is most liked by the family, preferred by kids, easy to prepare, easy to store, although causes Agnimandhya and Ama. Consuming excess food when the mood is not good (stress, fear, worry) or stress eating causes weight gain, diminished metabolic activities, lethargy conditions. Therefore, in the preventive as well as the curative aspect of $\mathrm{Ag}$ nimandya, lifestyle modification is very essential. By following the proper Ahara Vidhi, Vihara and Achara, it is possible to prevent and cure these diseases and regain a physically and psychologically healthy life.

\section{CONCLUSION}

In this study, it is evident that the majority of Hypothyroidism diagnosed subjects followed unwholesome regimens which may have caused Agnimandhya and ultimately landed in hypothyroidism. The survey study establishes the involvement of unhealthy diet and lifestyle to be the root cause of metabolic disorders such as hypothyroidism. Unhealthy lifestyles, stress and exposure to chemicals are believed to increase the risk of developing thyroid disorders. Approaching thyroid disease from a holistic level and seeing the body as an interconnected system is the better way to address disease. Many recent studies show dietary intervention offers a promising result in treating thyroid diseases. Therefore, a strict eliminating diet to soothe gut inflammation, restore digestive health, and address autoimmune diseases from a holistic approach could be the best way to prevent or treat thyroid diseases.

\section{REFERENCES}

1. Harishastri P, editor. Ashtanga Hridaya of Vagbhata, Nidana Sthana. Reprint. 9th Edition. Varanasi: Chaukhamba Orientalia; 2005. p. 513. Ch. 12, Ver. 1.

2. Yadavji Trikamji Acharya Susrutha Samhita of Susruta with the Nibandhasangraha Commentary of Sri Dalhanacharya Varanasi; Chaukhamba Surbharati Prakashan;2012. Sloka [Su. Su. 24/9]; p.116.

3. Metso S, Hyytiä-Ilmonen H, Kaukinen K, Huhtala H, Jaatinen P, Salmi J, Taurio J, Collin P. Gluten-free diet and autoimmune thyroiditis in patients with celiac disease. A prospective controlled study. Scand J Gastroenterol. $\quad 2012 \quad$ Jan;47(1):43-8. DOI: 10.3109/00365521.2011.639084. Epub 2011 Nov 30. PMID: 22126672.

4. Kar Soon, Tan \& Ting, Poh. Thyroid Diseases and Diet Control.Journal of Nutritional Disorders \& Therapy.08. 10.4172/2161-0509.1000224.2018; 8 (1):1-5

5. Damiri B, Khatib O, Nazzal Z, et al. Metabolic Syndrome Associated with Tobacco and Caffeine Products Use Among Refugee Adolescents: Risk of Dyslipidemia. Diabetes Metab Syndr Obes. 2021; 14:4121-4133. Published 2021 Sep 29. doi:10.2147/DMSO.S32967

6. Bajaj JK, Salwan P, Salwan S. Various Possible Toxicants Involved in Thyroid Dysfunction: A Review. J Clin Diagn Res. 2016;10(1): FE01-FE3. doi:10.7860/JCDR/2016/15195.7092

\section{Source of Support: Nil Conflict of Interest: None Declared}

How to cite this URL: Pavan Kumar K \& Sudhakar P Reddy: A Cross-Sectional Study To Assess The Impact Of Diet \& Lifestyle In Prevalence Of Hypothyroidism In Females - An Ayurvedic Perspective. International Ayurvedic Medical Journal \{online\} 2021 \{cited December 2021\} Available from: http://www.iamj.in/posts/images/upload/2971_2974.pdf 